\title{
Kirshner, J.A. (2019). Broke: Hardship and Resilience in a City of Broken Promises. St. Martin's Press.
}

\section{Review by John P. Beck}

Jodie Adams Kirshner teaches bankruptcy law at Columbia University. In 2016, she turned her attention to Detroit, the site of the largest municipal bankruptcy in the nation's history. Kirshner decided to move beyond recounting the simple mechanics of bankruptcy to look instead at the political, economic and social forces which formed the context for the bankruptcy decision and its aftermath. Kirshner conducted over 200 interviews with city residents to focus her exploration on the issues of day-to-day living in Detroit before, during, and after the declaration of bankruptcy. Bankruptcy has been used as a valuable tool for regaining solvency in some municipalities who faced natural disasters, for example, but Kirshner believes that the design and scale of Detroit's bankruptcy could not address the enormity of the problems the city faced, which were outside of its control. True control resided instead in the hands of state and national governments. The Detroit bankruptcy was triggered by the use of a state-appointed 'emergency manager,' working outside the bounds of elected city leaders to force change on the city. It was no accident that the school systems and local governments put under this form of state control in Michigan were all primarily African-American communities. Crippling costs were blamed on city residents in Detroit, though other communities in Southeastern Michigan refused to acknowledge the regionalism from which they were net gainers and Detroit net losers. As housing values dropped in Detroit, the city's tax base shrunk, leading to a cash-strapped city with nearly 150 square miles within which to provide police and fire, lighting and water, trash removal, and parks.

Kirshner uses the lives of seven Detroiters - Miles, Charles, Robin, Reggie, Cindy, Joe, and Lola (five men, two women, four Blacks, three whites) - to tell the broader, multi-faceted story of the city and the broken system all seven navigate to simply survive. All four of the African-Americans are in precarious employment. Their jobs are made even more precarious by a lack of dependable transportation - either public transportation, which was purposefully stopped from giving urban Blacks access to the suburbs where many work, or private vehicles which are subject to the highest insurance costs in the state. Both white men have come to Michigan because they perceive Detroit as a place where they can build an economic future involving real estate development.

The key common factor in all seven people's stories in Broke is real estate. Houses and land sit at the intersection of investment, taxation, neighborhood blight, and the aspiration to have a secure home. Declining housing costs and foreclosures fueled speculation and quick-buck investment by the haves and neighborhood degradation and uncertainty for the have nots. When homes that they had lost in foreclosure came up for auction, many Black Detroiters were locked out of the opportunity to own because the home values were too low for loan financing, but prices were still too high to buy with limited cash. Some homeowners turned to land contract arrangements, but ultimately lost their homes when predatory sellers had not disclosed (because they were not legally required to do so) that local taxes and fees were not being paid properly by the seller. When any 
of the Black Detroiters in Broke seem poised to move forward, they were dragged down by costs beyond their means, which forced them to confront the realization that their dream of home ownership may exceed their grasp. As William, Reggie's cousin, stated about adversity, 'We don't cry, we just move on.'

The Detroit of Broke is not only a community of have nots, but of haves as well. Detroit has enclaves of success and development. It is the Detroit of Quicken Loan's Dan Gilbert, Midtown; the renamed Cass Corridor, and the phoenix-like rebirth of the Art Deco Detroit train station into Ford Motor's new center for the 21st century rise of mobility. Some of the book's subjects live in neighborhoods that are slated to be the next comeback success stories.

Kirshner has succeeded in showing how state politics, regional tensions, taxation and insurance inequities, the criminal 'justice' system, and systemic racism have ensured that the poor, primarily African-American, residents of Detroit seemingly can never get a break from being knocked down again and again. One of the strongest recurring themes in the book has to do with the ways in which traffic citations and court fees were added to Detroit residents' tax bills, which then led to tax-based foreclosure and home loss. Even the smallest fees and costs mount up to become insurmountable for the poor. The inability to pay bail when jailed, for example, can lead to missing work, which means less money to cover costs and the spiral continues.

Kirshner has juxtaposed three uses of the word 'broke' in this book. First and foremost, she is using the word to denote the economic hardships of the City of Detroit, an economic condition made worse and not better by governmental action. The second meaning of 'broke' has to do with her notion that the failures of government led to broken promises to Detroit and its residents (and in some cases from Detroit to its residents). The third use is evident in her story of these seven men and women in Detroit who 'hope for better days,' as she says in the title of her epilogue. That hope is part of the resilience captured in her sub-title and in the stories of the seven Detroiters.

There are other meanings of 'broke' that may be appropriate to consider when reading Kirshner's book. First, I think that you cannot read this book and not see the trauma that these four AfricanAmerican men and women endure. Yes, they are resilient, but the compound inequities and indignities they face are real and traumatic. Second, the systems that should support Detroit and its residents are truly broken. It is now a daunting challenge, for example, as vast areas of Detroit must be lit when only a handful of houses on any street are occupied. This is not to say that services should be stopped, but great creativity and resolve must be brought to bear on the problems of Detroit; solutions for Detroit can inform decision-making across the wider world. A proper taxation system for Detroit which pulls in regional cooperation, an end to faulty development through tax breaks, and real State of Michigan responsibility are logical places to start.

The degradation of Black working-class Detroit, like its neighbor Flint an hour north, was not done overnight, nor was it accidental. Black lives matter every day, not only because of senseless police slayings of individuals, but because of the wholesale betrayal of Black working-class communities like Detroit. The resilience of these Detroiters should not be mistaken for acceptance or resignation. 
Broke is an important book. Kirshner brings her knowledge of bankruptcy to the case of Detroit and does a good job of exploring larger economic and social trends through the lives of her seven subjects. Kirshner has added nicely to the literature of Detroit which aims to overcome a vision of the Motor City as simply a post-industrial wasteland.

\section{Reviewer Bio}

John P. Beck teaches in the Labor Education Program at Michigan State University. For nearly thirty years, he has co-directed Our Daily Work/Our Daily Lives, a program on workers culture at MSU. In 2014, he co-edited Detroit Resurgent, a book profiling individuals attempting to reinvent the Motor City. 